\title{
In Vitro and In Vivo Feedstuff Digestibility for Snook, Centropomus undecimalis, Juveniles
}

\author{
IRATZIO LEMUS \\ Posgrado de Ciencias del Mar y Limnología, Universidad Nacional Autónoma de Mexico, \\ Avenida Universidad 3000, Col. UNAM-CU, cp 04510, Coyoacan, Mexico \\ Carlos Maldonado, Gerard Cuzon, Adolfo Sanchez, and Gabriela Gaxiola ${ }^{1}$ \\ Unidad Multidisciplinaria de Docencia e Investigación de Sisal, Facultad Ciencias, Universidad \\ Nacional Autónoma de Mexico, Puerto de Abrigo S/N Hununcmá, Yucatán cp 97355, México \\ Alfonso Alvarez \\ Laboratorio de Acuicultura Tropical, DACBIOL. Universidad Juárez Autónoma de Tabasco. \\ Carrtera Villaermosa-Cárdenas km 0.5. Villahemrosa, Tabasco, cp 86150, México \\ Martha Guerrero \\ Instituto de Biotecnología, Facultad de Ciencias Biológicas, Universidad Autónoma de Nuevo \\ León, Ave Pedro de Alba S/N; San Nicolás de los Garza, Nuevo Léon, México
}

\begin{abstract}
The degree of hydrolysis (DH) of the ingredients was evaluated for Centropomus undecimalis juveniles. The in vitro experiment included wheat gluten (WG), corn gluten (CG), soybean meal (SBM) and pretreated phytase (SBM + phytase), soy protein concentrate (SPC), canola meal (CAN) and pretreated phytase (CAN + phytase), poultry byproduct meal (PBPM), chicken meal (CHKM), dried whey (DW), Pota meal (PM: mix of giant squid, fish soluble protein concentrate, crustacean meal, and fish oil), and Protiblend (PTB: aquatic and render mix). The highest acidic DH occurred with PTB $(0.38 \pm 0.06)$, CHKM $(0.33 \pm 0.3)$, and PBPM $(0.25 \pm 0.03)$. In the alkaline condition, PTB $(1.6 \pm 0.17$ and $0.98 \pm 0.05$ for pyloric caeca and intestine, respectively) and CG $(1.04 \pm 0.4$ and $0.75 \pm 0.2$ for caeca and intestine, respectively) provided the highest $\mathrm{DH}$ values. In vitro digestibility demonstrated that PTB was the highest $(85.3 \%)$ followed by PBPM (51.4\%), CAN + phytase (47.6\%), CG (45.1\%), and CHKM (46.5\%). The in vivo experiment concerned the WG, CHKM, PBPM, PM, and PTB diets plus a reference diet with fishmeal (Ref diet). The total \% DH was different $(P<0.05)$ with the lowest values for the WG $\operatorname{diet}(0.34 \pm 0.09 \%)$ and Ref diet $(0.34 \pm 0.15)$. Free amino acid released during digestion was displayed for these diets and a bifactorial analysis produced no difference $(P>0.05)$. The apparent digestive coefficients ranged from 89.8 to $92.9 \%$ for protein and from 68 to $71.4 \%$ for energy.
\end{abstract}

\section{KEYWORDS}

amino acids, in vitro and in vivo digestibility, pH-stat, protein, snook

The highest cost in finfish aquaculture is the feed, and the protein content represents the greatest proportion. Therefore, looking for alternative protein sources to replace traditional ones, such as marine sources (Córdova-Murueta and García-Carreño 2002), is a prerequisite for

\footnotetext{
${ }^{1}$ Correspondence to: mggc@ ciencias.unam.mx
}

sustainable production. Among these parameters, the digestibility of the ingredients provides a primary idea of the body's ability to use them (Moyano and Savoie 2001; Alarcon et al. 2002; Barroso et al. 2002; Garcia-Lopez et al. 2003; Soria-Cuenca et al. 2013).

In vitro and in vivo methods for measuring protein utilization by fish were found to be 
complementary (Dimes et al. 1994a, 1994b). In vitro digestibility studies led to a determination of ingredient quality to evaluate possible savings and created a shortlist of potential sources (Ezquerra et al. 1997; Tibbetts et al. 2011). pH-Stat was previously used in research on human and fish screening among protein ingredients, and Pedersen and Eggum (1983) found reasonable accuracy in predicting digestibility. Based on this method, Dimes and Haard (1994) and Dimes et al. (1994a, 1994b) assessed salmonid feedstuffs. Later, Alarcon et al. (2002) and Silva et al. (2014) found a significant correlation between in vitro and in vivo digestibility for fish (Gomes Da Silva and Oliva-Teles 1998) to optimize protein fractions in a microencapsulated feed for marine fish larvae.

Meanwhile, several authors (Lee and Lawrence 1986; Smith and Tabrett 2008; Silva et al. 2014) worked on in vivo digestibility for marine fish to screen various ingredients and to formulate a grower feed using direct (gravimetric) or indirect (inert marker) methods (Cuzon et al. 1998).

Centropomus parallelus gut histological sections previously showed that proteins and lipids were absorbed mostly by the caeca, whereas only protein was absorbed in the rectum (Shimada et al. 2010).

The objective of the present study was to identify the most digestible ingredients among a series of feedstuffs to formulate a practical diet for the common snook, Centropomus undecimalis, and to be produced in controlled conditions.

\section{Materials and Methods}

In Vitro Digestibility

Fifteen snook were obtained from one spawning in the laboratory Unidad Multidisciplinaria de Docencia e Investigación de Sisal, UNAM, Mexico, and the larvae were reared according to Ibarra-Castro et al. (2011) to obtain juveniles fed on a commercial feed for their growout.

After the fish fasted for $48 \mathrm{~h}$, they were transferred to the laboratory for analysis and kept in a 10-L container with seawater added with $0.1 \mathrm{~mL}$ clove oil/L as an anesthetic. Biometric measurements (total and standard length, max and min height, and weight) were recorded, and later, the fish were sacrificed to remove the stomach, caeca, and intestine. Each organ was deposited on ice in a beaker, placed in containers, and rinsed with distilled water. The organs were individually weighed and stored in bags at $-80 \mathrm{C}$ until ready for analysis.

Proximate analyses of the ingredients followed AOAC (1980) methods: this method consisted of nitrogen by elemental analysis based on direct and spontaneous sample combustion in an atmosphere of pure $\mathrm{O}_{2}$ at 950-1400 C. $\mathrm{CHN}$ and $\mathrm{S}$ are transformed to $\mathrm{CO}_{2}, \mathrm{~N}_{2}$, and $\mathrm{SO}_{2}$ and carried by $\mathrm{He}$ to a single infrared cell with $\mathrm{CO}_{2}$ and $\mathrm{SO}_{2}$ are removed. Then, $\mathrm{N}_{2}$ was measured by differential thermal conductivity; lipids were extracted by the Goldfish method and ash by incineration at $500 \mathrm{C}$ in a muffle oven. The energy content of the ingredients was measured in an adiabatic calorimeter bomb (PARR, Moline, IL, USA), which was previously calibrated with benzoic acid.

To reduce the phytic acid content from soybean meal (SBM) and canola (CAN) meal, both ingredients were pretreated with $\beta$-propeller phytase (FTEII) designed to have high thermostability and activity over a broad range of pH (Viader-Salvadó et al. 2010) according to the method of Saunders et al. (1972) and modified by Dimes and Haard (1994).

Five enzymatic extracts from the digestive tract of three fish were individually prepared according to Silva et al. (2014). The stomach, pyloric caeca, and intestine were macerated in an Ultra Turrax ${ }^{\circledR}$ tissue homogenized with distilled water at $15: 1(15 \mathrm{~mL} / \mathrm{g}$ tissue $)$ and the mash was placed in 2-mL Eppendorf tubes and centrifuged at $16,170 \mathrm{~g}$ for $15 \mathrm{~min}$ at $4 \mathrm{C}$. Then, the middle layer was transferred to another Eppendorf tube and stored at $-20 \mathrm{C}$.

Acidic and alkaline protease activities (Kunitz 1947, modified by Walter 1984) were obtained from enzyme extracts of the stomach, pyloric caeca, and intestine. For the acidic protease analysis, a 2-mL Eppendorf tube received hemoglobin $(\mathrm{Hb})(1 \%)$ in glycine buffer and $0.1 \mathrm{M} \mathrm{HCl}$ to $\mathrm{pH} 2$ and $5 \mu \mathrm{L}$ of enzyme extract 
was added and incubated for $5 \mathrm{~min}$ at $37 \mathrm{C}$. The reaction was stopped with $0.5 \mathrm{~mL}$ trichloroacetic acid (TCA) (20\%) for $15 \mathrm{~min}$ at $4 \mathrm{C}$ to precipitate the protein, the mixture was centrifuged at $13,370 \mathrm{~g}$ for $5 \mathrm{~min}$ at $4 \mathrm{C}$, and the supernatant absorbance was read at $280 \mathrm{~nm}$.

For the alkaline protease analysis, a $2-\mathrm{mL}$ Eppendorf tube received $0.5 \mathrm{~mL}$ casein $(1 \%)$ at $\mathrm{pH} 9$ and $0.5 \mathrm{~mL}$ of buffer Tris $-\mathrm{HCl}$ $100 \mathrm{mM}+\mathrm{CaCl}_{2} 10 \mathrm{mM}$ and $10 \mu \mathrm{L}$ of enzyme extract and was incubated for $40 \mathrm{~min}$ at $37 \mathrm{C}$. The reaction was stopped with $0.5 \mathrm{~mL}$ TCA (20\%) for $15 \mathrm{~min}$ at $4 \mathrm{C}$ to precipitate the protein, the mixture was centrifuged for $5 \mathrm{~min}$ at $13,370 \mathrm{~g}$, and the absorbance was measured at $280 \mathrm{~nm}$; the enzymatic unit per milliliter was calculated as follows:

$$
\begin{gathered}
\mathrm{U} / \mathrm{mL}=\Delta \mathrm{abs}_{280 \mathrm{~nm}} \\
\times \text { final volume of reaction }(\mathrm{mL})
\end{gathered}
$$

$\overline{\mathrm{CEM}_{\text {Tyrosine }} \times \text { time } \times \text { extracted volume }(\mathrm{mL})}$

where CEM is the molar extinction coefficient, incubation time in minutes, and the amount of extract per milliliter.

Eleven ingredients were tested on a $\mathrm{pH}-\mathrm{Stat}$ (Metrohm 842 Titrando) for DH determination on stomach (acidic), caeca, and intestine (alkaline) with a final volume of $5 \mathrm{~mL}$ distilled water and an equivalence of $8 \mathrm{mg}$ protein $/ \mathrm{mL}$. The hydrolysis was conducted at $37 \mathrm{C}$ for $15 \mathrm{~min}$ (stomach) and $45 \mathrm{~min}$ (caeca and intestine). The $\mathrm{HCl} 0.1 \mathrm{~N}$ maintained the $\mathrm{pH} 3.5$ for acidic in vitro digestibility and $\mathrm{NaOH} 0.1 \mathrm{~N}$ was used for alkaline digestibility. $\mathrm{Hb}$ was used as a reference ingredient in the acidic digestibility and Hammerstein casein was used for alkaline digestibility. The unit number (tissue $\mathrm{U} / \mathrm{mL}$ ) for in vitro digestibility was displayed as follows: stomach (pool 1-3) 4611-5161, caeca (pool 1-3) 151-330, and intestine (pool 1-3) 26-188. The final volume of both $\mathrm{HCl}$ and $\mathrm{NaOH}$ served to determine that the $\mathrm{DH}=h / h_{\mathrm{tot}} \times 100$, where $h$ is the number of hydrolyzed peptide links and $h_{\text {tot }}$ is the total number of peptide links of the protein substrate. The number of hydrolyzed peptide links was calculated as $h=V_{\mathrm{b}} \times N_{\mathrm{b}} \times 1 / \alpha \times 1 / \mathrm{MP}$, where $V_{\mathrm{b}}$ is the volume of the base consumed $(\mathrm{mL}), N_{\mathrm{b}}$ is the normality of the base, $\alpha$ is the constant of dissociation for the $\alpha-\mathrm{NH}_{2}$ groups, and $M_{\mathrm{P}}$ is the mass of the protein in the mix for the reaction.

To determine the DH of the different diets, $200 \mu \mathrm{L}$ were sampled for acidic digestion at 0 , 3 , and $15 \mathrm{~min}$ and for alkaline digestion at 0,30 , and $45 \mathrm{~min}$. These samples were mixed with an equal $12 \%$ TCA volume and then stored at $-80 \mathrm{C}$ for subsequent tests such as an analysis of total amino acids by electrophoresis (Izquierdo et al. 2001; Silva et al. 2014).

The free amino acid (FAA) analysis is based on the reaction with the $\alpha$-amino o-phthalaldehyde (OPA) and $\beta$-mercaptoethanol OPA solution, which was mixed with $25 \mathrm{~mL}$ of sodium tetraborate $(100 \mathrm{mM}), 2.5 \mathrm{~mL}$ of $20 \%$ sodium dodecyl sulphate, $40 \mathrm{mg}$ of OPA dissolved in $1 \mathrm{~mL}$ methanol, $100 \mu \mathrm{L}$ of $\beta$-mercaptoethanol, and $50 \mathrm{~mL}$ pyrogen-free water prepared daily. The $25-\mu \mathrm{L}$ samples plus $1 \mathrm{~mL}$ OPA solution were briefly mixed and incubated for $2 \mathrm{~min}$ at room temperature, and the absorbance was read at $340 \mathrm{~nm}$. The total amino acid analysis (TAAA) $(\mathrm{mg} / \mathrm{mL})$ of the reaction referred to a standard curve with L-leucine $(0.5 \mathrm{mg} / \mathrm{mL})$ for the $200-\mu \mathrm{L}$ sample of acidic digestion at 0.7 (15 min) and in alkaline digestion at 0.3 (45 min). Blind samples for intestine occurred at three time points $(0$, 30 , and $45 \mathrm{~min}$ ) and were mixed with an equal volume of $12 \%$ TCA and stored at $-80 \mathrm{C}$. This procedure was repeated in triplicate for each diet (Church et al. 1983).

\section{In Vivo Digestibility}

A total of 180 juveniles with a $45-\mathrm{g}$ mean wet weight were placed in eighteen 100-L tanks (10 fish/tank) in a closed recirculation system with controlled parameters. A randomized experimental design with six treatments and three replicates per treatment was used. The fish were fed 3\% of their biomass daily at 0900, 1300, and $1800 \mathrm{~h}$ (Garcia-Galano et al. 2003).

Six diets were prepared according to Silva et al. (2014); (Table 1). Raw materials were screened at $250 \mu \mathrm{m}$ and mixed for $10-15 \mathrm{~min}$. The oil was mixed for $10-15 \mathrm{~min}$, and the binder was gelatinized by adding boiling water and stirring until the dough was extruded through a meatmincer to form pellets, which were stored 
TABLE 1. Diet composition for the in vivo digestibility experiment of juvenile Centropomus undecimalis. ${ }^{1}$

\begin{tabular}{|c|c|c|c|c|c|c|}
\hline Ingredients & $\begin{array}{c}\text { Reference } \\
\text { diet }\end{array}$ & $\begin{array}{c}\text { Wheat } \\
\text { gluten diet }\end{array}$ & $\begin{array}{c}\text { Pota meal } \\
\text { diet }\end{array}$ & $\begin{array}{l}\text { Chicken } \\
\text { meal diet }\end{array}$ & $\begin{array}{l}\text { Soybean } \\
\text { meal diet }\end{array}$ & $\begin{array}{c}\text { Protiblend } \\
\text { diet }\end{array}$ \\
\hline Wheat gluten Viten ${ }^{2}$ & & 30 & & & & \\
\hline Poultry byproduct meal ${ }^{3}$ & & & 30 & & & \\
\hline Chicken meal ${ }^{3}$ & & & & 30 & & \\
\hline Giant squid meal $^{4}$ & & & & & 30 & \\
\hline Protiblend ${ }^{5}$ & & & & & & 30 \\
\hline Anchovy meal ${ }^{6}$ & 70 & 49 & 49 & 49 & 49 & 49 \\
\hline Wheat flour ${ }^{6}$ & 21 & 15 & 15 & 15 & 15 & 15 \\
\hline Cod liver oil ${ }^{7}$ & 3 & 2.1 & 2.1 & 2.1 & 2.1 & 2.1 \\
\hline Soy lecitin ${ }^{7}$ & 1 & 0.7 & 0.7 & 0.7 & 0.7 & 0.7 \\
\hline Min + vit premix ${ }^{8}$ & 2 & 1.4 & 1.4 & 1.4 & 1.4 & 1.4 \\
\hline Carboxymethyl-cellulose $\mathrm{e}^{10}$ & 1 & 0.7 & 0.7 & 0.7 & 0.7 & 0.7 \\
\hline Zeolite $^{9}$ & 1.5 & 1.1 & 1.1 & 1.1 & 1.1 & 1.1 \\
\hline Crude protein & 63.75 & 61.74 & 55.3 & 59.62 & 60.36 & 60.23 \\
\hline Fat & 9.47 & 13.87 & 13.33 & 13.6 & 11.06 & 12.71 \\
\hline Carbohydrate & 13 & 9 & 9 & 9 & 9 & 9 \\
\hline Ash & 9.13 & 10.13 & 12.96 & 12.29 & 12.78 & 14.67 \\
\hline Gross energy $(\mathrm{kJ} / \mathrm{g})$ & 9.7 & 12.3 & 11.1 & 11.0 & 10.1 & 11.4 \\
\hline
\end{tabular}

${ }^{1}$ The results are expressed in \% wet weight using the AOAC (1980) method for proximate analysis.

${ }^{2}$ Roquette Frères S.A., Francia.

${ }^{3}$ MaltaCleyton S.A. de C.V., Mérida, Yucatán, Mexico.

${ }^{4}$ IMPEXCO, Peru.

${ }^{5}$ Soluciones Integrales de Nutrición SA de CV, Mexico.

${ }^{6}$ Productos Químicos de Yucatán S.A. de C.V., Mérida, Yucatán, Mexico.

${ }^{7}$ Proteínas y Oleicos S.A. de C.V., Mérida, Yucatán, Mexico.

${ }^{8}$ DMS Nutritional Products Mexico S.A. de C. V., Mexico.

${ }^{9}$ Wachsen Industry Co., Ltd., Quingdao, China.

${ }^{10}$ Comercializadora Mayorista del Golfo S.A. de C.V., Mérida, Yucatán, Mexico.

TABLE 2. Free amino acid concentrations $(\mu \mathrm{g} / \mathrm{mL})$ released from acidic and alkaline hydrolysis using 268 multi-enzymatic extracts of the juvenile Centropomus undecimalis on protein ingredients (mean $\pm E S, \mathrm{n}=3$ ): reference diet (Refd), wheat gluten diet (WGd), chicken meal diet (CHKMd), poultry byproduct diet (PBPd), Pota meal diet (PMd), and Protiblend diet $(P T B d){ }^{1}$

\begin{tabular}{|c|c|c|c|c|c|c|c|c|c|}
\hline \multirow[b]{2}{*}{ Diet } & \multicolumn{4}{|c|}{ Stomach } & \multicolumn{3}{|c|}{ Caeca } & \multicolumn{2}{|c|}{ Intestine } \\
\hline & $t_{0}$ & $6 \mathrm{~min}$ & $15 \mathrm{~min}$ & $t_{0}$ & $30 \mathrm{~min}$ & $45 \mathrm{~min}$ & $t_{0}$ & $30 \mathrm{~min}$ & $45 \mathrm{~min}$ \\
\hline Refd & $1.4 \pm 0.2^{\mathrm{a}}$ & $1.8 \pm 0.04^{\mathrm{a}}$ & $1.7 \pm 0.1^{\mathrm{a}}$ & $0.23 \pm 0.1^{\mathrm{ab}}$ & $2.3 \pm 0.5^{\mathrm{a}}$ & $2.3 \pm 0.3^{\mathrm{a}}$ & $2.2 \pm 0.2^{\mathrm{a}}$ & $3.7 \pm 0.6^{\mathrm{a}}$ & $3.3 \pm 0.3^{\mathrm{a}}$ \\
\hline WGd & $0.2 \pm 0.04^{\mathrm{c}}$ & $0.05 \pm 0.1^{\mathrm{c}}$ & $0.4 \pm 0.07^{\mathrm{c}}$ & $0.26 \pm 0.3^{b}$ & $1.2 \pm 0.3^{b}$ & $1.2 \pm 0.2^{\mathrm{a}}$ & $0.7 \pm 0.3^{b}$ & $2.4 \pm 0.5^{\mathrm{a}}$ & $2.4 \pm 0.4^{\mathrm{a}}$ \\
\hline CHKMd & $0.8 \pm 0.06^{b}$ & $1.05 \pm 0.08^{\mathrm{ab}}$ & $1.2 \pm 0.08^{\mathrm{ab}}$ & $0.9 \pm 0.2^{\mathrm{ab}}$ & $1.9 \pm 0.00^{\mathrm{a}}$ & $2.2 \pm 0.3^{\mathrm{a}}$ & $1.44 \pm 0.5^{\mathrm{ab}}$ & $3.3 \pm 0.6^{\mathrm{a}}$ & $3.0 \pm 0.5^{\mathrm{a}}$ \\
\hline PBPd & $0.9 \pm 0.1^{b}$ & $1.1 \pm 0.2^{\mathrm{ab}}$ & $1.2 \pm 0.2^{\mathrm{ab}}$ & $1.03 \pm 0.6^{\mathrm{ab}}$ & $2.6 \pm 0.7^{\mathrm{ab}}$ & $2.8 \pm 0.9^{\mathrm{ab}}$ & $1.4 \pm 0.6^{\mathrm{ab}}$ & $3.2 \pm 0.4^{\mathrm{a}}$ & $3.3 \pm 0.4^{\mathrm{a}}$ \\
\hline PMd & $0.9 \pm 0.2^{\mathrm{b}}$ & $1.05 \pm 0.03^{b c}$ & $1.1 \pm 0.1^{\mathrm{bc}}$ & $1.45 \pm 0.3^{\mathrm{a}}$ & $2.5 \pm 0.3^{\mathrm{a}}$ & $2.5 \pm 0.4^{\mathrm{ab}}$ & $1.2 \pm 0.4^{\mathrm{ab}}$ & $3.3 \pm 0.7^{\mathrm{a}}$ & $3.6 \pm 1.3^{\mathrm{a}}$ \\
\hline PTBd & $0.8 \pm 0.03^{b}$ & $0.96 \pm 0.0 \mathrm{bc}^{\mathrm{a}}$ & $1.03 \pm 0.09^{b c}$ & $1.11 \pm 0.1^{\mathrm{a}}$ & $2 \pm 0.1^{\mathrm{ab}}$ & $2.0 \pm 0.3 b^{a}$ & $1.44 \pm 0.4^{\mathrm{ab}}$ & $3.2 \pm 0.4^{\mathrm{a}}$ & $3.3 \pm 0.6^{\mathrm{a}}$ \\
\hline
\end{tabular}

${ }^{1}$ Different letters in superscript indicate significant differences $(P<0.05)$.

at $40 \mathrm{C}$ (Table 2). To quantify apparent digestive coefficient of ingredient $\left(\mathrm{ADC}_{\text {ingredient }}\right)$ and $\mathrm{ADC}$, the fish fasted for $48 \mathrm{~h}$ and were then fed. The collection of feces started $2 \mathrm{~d}$ after the feeding started (Borquez and Cerqueira 1998; Wainwright et al. 2006). Daily and before each feeding, the waste was removed from the tanks by siphoning using a 3-mm-diameter plastic tube. After feeding (30 min later), unconsumed feed was also removed from the tanks. The feces were removed each hour between each feeding by siphoning using a plastic tube and cellulose paper. After daily collection, the feces were washed with distilled water and dried at $60 \mathrm{C}$.

A randomized design included six treatments with three replicates. $\mathrm{ADC}_{\mathrm{DM}}$ and 
TABLE 3. Proximal analysis of the ingredients used in this study.

\begin{tabular}{|c|c|c|c|c|c|c|c|}
\hline Ingredient & Moisture & Ash & $\mathrm{EE}$ & $\mathrm{CP}$ & NFE & Cellulose & GE kJ/g \\
\hline Chicken meal & 3.93 & 12.46 & 12.64 & 66.85 & & - & 16 \\
\hline Poultry byproduct & 3.81 & 16.73 & 14.73 & 62.47 & 1 & - & 20.3 \\
\hline Protiblend & 4.90 & 14.54 & 8.45 & 68.77 & & - & 15 \\
\hline Pota meal & 7.84 & 6.62 & 14.01 & 55.26 & 16 & - & 15 \\
\hline Dried whey & 2.47 & 7.85 & 0.22 & 12.84 & 48 & - & 16 \\
\hline Corn gluten & 5.04 & 1.56 & 2.35 & 69.19 & 22 & 1.5 & 19.8 \\
\hline Wheat gluten & 6.78 & 0.90 & 1.76 & 80.82 & & - & 22 \\
\hline Canola meal & 4.86 & 7.10 & 1.72 & 44.77 & 41 & 13 & 17 \\
\hline SBM & 7.01 & 6.95 & 1.77 & 51.21 & 33 & 3.5 & 18.9 \\
\hline Soy protein concentrate & 4.80 & 6.79 & 0.23 & 66.66 & 22 & 2 & 19 \\
\hline SBM + phytase & 7.01 & 6.95 & 1.77 & 51.21 & 33 & 3.5 & 18.9 \\
\hline Canola meal + phytase & 4.86 & 7.10 & 1.72 & 44.77 & 41 & 13 & 17 \\
\hline
\end{tabular}

$\mathrm{CP}=$ crude protein $; \mathrm{EE}=$ ether extract $\mathrm{GE}=$ gross energy; $\mathrm{NFE}=$ nitrogen free extract; $\mathrm{SBM}=$ soy bean meal.

$\mathrm{ADC}_{\text {proteín }}(\mathrm{DM}=$ dry matter $)$ were measured using zeolite as a marker (silica as a frustule component of diatomaceous earth), and samples were incinerated in a muffle furnace with crucibles to reach $500 \mathrm{C}$. The six diets included a known amount, and the feces were collected to calculate the following formula: $\mathrm{ADC}_{\mathrm{DM}}=100 \times(1-(\%$ zeolite diet $/ \%$ zeolite in feces $) ; \mathrm{ADC}_{\text {proteín }}=100 \times(1-(\%$ zeolite diet $/ \%$ zeolite feces) $(\%$ crude protein feces $/ \%$ crude protein diet); and $\mathrm{ADC}_{\text {energy }}=100 \times(1-(\% \quad$ zeolite $\operatorname{diet} / \%$ zeolite feces) (energy feces/energy diet). $\mathrm{ADC}_{\text {ingredient }}=\mathrm{ADC}_{\text {test diet }}+\left(\left[\mathrm{ADC}_{\text {test diet }}-0.7\right.\right.$

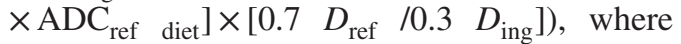
$D=\%$ CP (Bureau and Hua 2006).

\section{Statistical Analysis}

For the differences between the DH values of the ingredients, the $\mathrm{DH}$ of the diets, and the ADC coefficients of the diets and ingredients, the one-way ANOVA was used. The FAA values were analyzed using a bifactorial ANOVA to consider the time of sampling and treatments as factors. When significant differences were observed, the Tukey multiple range test was used to detect a difference at the $5 \%$ confidence level. If homogeneity of the variance was not met, a Kruskal-Wallis test was used and the results reported as median \pm quartile range. Lineal regression was calculated to correlate the $\mathrm{DH}$ of the ingredient and the apparent digestibility coefficients.

\section{Results}

The proximate composition ranges of the ingredients were as follows: moisture $(2-8 \%)$, crude protein $(13-69 \%)$, ether extract $(0.2-15 \%)$, and ash $(1-17 \%)$ (Table 3$)$.

The in vitro acidic digestibility of the plant protein ingredients was lower than those from an animal origin (from $0.05 \pm 0.01$ for wheat gluten [WG] to $1.04 \pm 0.4$ for corn gluten [CG] compared to $0.6 \pm 1.5$ for Pota meal [PM] and $1.6 \pm 0.17$ for Protiblend [PTB]; Table 4).

The in vitro alkaline digestibility results from the pyloric caeca showed that PTB meal (PTBM) $(1.6 \pm 0.1)$ achieved the highest value $(P<0.05)$. For the intestine, the highest DH value was also obtained for PTBM $(1 \pm 0.04)$. The lowest significant values in both the pyloric caeca and the intestine were obtained with WG meal (Table 4).

The total DH values of each feedstuff indicated that PTBM had the highest value $(2.99 \pm 0.29 \%)$, which represented $85.3 \pm 4.5 \%$ compared to the reference $\mathrm{Hb} /$ casein. The best plant protein ingredients were $\mathrm{CAN}+$ phytase $(1.76 \pm 0.3$ and $46.5 \pm 9.2 \%)$ and CG meal $(1.6 \pm 0.2$ and $45.1 \pm 6 \%$ ). Similarly, total DH was obtained in poultry byproduct (PBP) meal $(1.9 \pm 0.5$ and $51.4 \pm 1.5 \%)$ and chicken meal (CHKM) $(1.72 \pm 0.3$ and $46.5 \pm 9.2 \%)$.

The DH of the diets formulated for the in vitro digestibility experiment showed significant differences in the stomach and pyloric caeca, where the lowest significant value was obtained in the WG diet and the highest value in the PTB diet (Table 5). For the intestine, the values 
TABLE 4. Degree of hydrolysis (DH) for various sources of protein using enzymatic extracts from the stomach (according to a one-way ANOVA, mean $\pm S E$ ); the pyloric caeca and intestine of juveniles of Centropomus undecimalis (according to Kruskal-Wallis test; median \pm quetile range). ${ }^{1}$

\begin{tabular}{|c|c|c|c|c|c|}
\hline & Stomach & Caeca & Intestine & Hemoglobin/casein & \\
\hline & \multicolumn{3}{|c|}{ DH } & DH total & $\%^{2}$ \\
\hline Hemoglobin/casein & $0.04 \pm 0.006^{\mathrm{b}}$ & $0.64 \pm 0.08^{\mathrm{a}}$ & $0.37 \pm 0.2^{\mathrm{a}}$ & $3.69 \pm 0.0^{\mathrm{a}}$ & \\
\hline Soybean meal (SBM) & $0.024 \pm 0.05^{\mathrm{b}}$ & $0.05 \pm 0.02^{\mathrm{ef}}$ & $0.11 \pm 0.07^{\mathrm{ef}}$ & $0.97 \pm 0.2^{\mathrm{de}}$ & $26.2 \pm 4.6^{\mathrm{c}}$ \\
\hline SBM + phytase $^{3}$ & $0.002 \pm 0.005^{\mathrm{b}}$ & $0.64 \pm 0.1^{\mathrm{def}}$ & $0.35 \pm 0.009^{\mathrm{def}}$ & $1.05 \pm 0.04^{\mathrm{de}}$ & $28.3 \pm 1^{\mathrm{c}}$ \\
\hline Soy protein concentrate ${ }^{4}$ & $0.009 \pm 0.01^{\mathrm{b}}$ & $0.8 \pm 0.08^{b c}$ & $0.34 \pm 0.1^{\mathrm{ef}}$ & $1.3 \pm 0.4^{\text {cde }}$ & $35.7 \pm 11^{\mathrm{c}}$ \\
\hline Canola meal & $0.027 \pm 0.02^{\mathrm{d}}$ & $0.8 \pm 0.2^{\text {cde }}$ & $0.18 \pm 0.18^{f}$ & $1.16 \pm 0.07^{\mathrm{de}}$ & $31.5 \pm 1.9^{c}$ \\
\hline Canola + phytase & $0.0097 \pm 0.01^{\mathrm{d}}$ & $0.9 \pm 0.6^{b c}$ & $0.7 \pm 0.7^{\mathrm{c}}$ & $1.76 \pm 0.5^{\mathrm{cd}}$ & $47.6 \pm 14^{\mathrm{b}}$ \\
\hline Corn gluten & $0.005 \pm 0.01^{\mathrm{bc}, \mathrm{d}}$ & $1.05 \pm 0.15^{\mathrm{b}}$ & $0.75 \pm 0.3^{\mathrm{c}}$ & $1.6 \pm 0.2^{\mathrm{cd}}$ & $45.1 \pm 6^{\mathrm{b}}$ \\
\hline Wheat gluten ${ }^{5}$ & $0.057 \pm 0.008^{b}$ & $0.013 \pm 0.007^{\mathrm{f}}$ & $0.02 \pm 0.01^{\mathrm{f}}$ & $0.18 \pm 0.0^{f}$ & $4.87 \pm 0.01^{\mathrm{d}}$ \\
\hline Protiblend $^{6}$ & $0.38 \pm 0.06^{\mathrm{a}}$ & $1.6 \pm 0.16^{\mathrm{a}}$ & $1 \pm 0.04^{\mathrm{b}}$ & $2.99 \pm 0.2^{\mathrm{b}}$ & $85.3 \pm 4.5^{\mathrm{a}}$ \\
\hline Chicken meal $^{7}$ & $0.08 \pm 0.02^{b}$ & $0.45 \pm 0.14^{\mathrm{bc}}$ & $0.45 \pm 0.15^{\mathrm{d}}$ & $1.72 \pm 0.3^{\mathrm{cd}}$ & $46.5 \pm 9.2^{\mathrm{b}}$ \\
\hline Dried whey & $0.33 \pm 0.3^{\mathrm{ab}}$ & $1.02 \pm 0.3^{\mathrm{bcd}}$ & $0.38 \pm 0.2^{\text {ef }}$ & $1.35 \pm 0.4^{\text {cde }}$ & $36.5 \pm 11^{\mathrm{c}}$ \\
\hline Poultry byproduct $^{7}$ & ND & $1.05 \pm 0.07^{b}$ & $0.6 \pm 0.2$ de & $1.9 \pm 0.05^{\mathrm{cd}}$ & $51.4 \pm 1.5^{\mathrm{b}}$ \\
\hline Pota meal ${ }^{8}$ & $0.25 \pm 0.03^{\mathrm{a}}$ & $0.6 \pm 0.16^{\mathrm{def}}$ & $0.21 \pm 0.1^{\mathrm{f}}$ & $00.84 \pm 0.2^{\mathrm{e}}$ & $22.8 \pm 5.8^{\mathrm{c}}$ \\
\hline
\end{tabular}

$\mathrm{ND}=$ none detected.

${ }^{1}$ The in vitro digestibility (\%) of the ingredients was examined in relation to a hemoglobin/casein standard (according to a one-way ANOVA, mean $\pm \mathrm{SE}$ ).

$2 \%$ Digestibility relative to hemoglobin/casein total hydrolysis.

${ }^{3}$ In this work, the beta-propeller phytases (FTEII) were designed to have high thermostability and activity over a broad range of $\mathrm{pH}$ (Viader-Salvadó et al. 2010) and were used for pretreatment of both the soybean and canola meal.

${ }^{4}$ Profine, Chile.

${ }^{5}$ Roquette frères, France.

${ }^{6} \mathrm{Mix}$ of aquatic and terrestrial animals produced by Soluciones Integrales de Nutrición, SA de CV, Mexico.

${ }^{7}$ Proteínas Marinas y Agropecuarias SA de CV, Mexico.

${ }^{8} \mathrm{~A}$ mix of giant squid meal, dehydrated fish soluble protein concentrate, crustacean meal, and fish oil and produced by Animal Feed SA de Cv, Mexico.

TABLE 5. The degree of hydrolysis (DH) (acid, alkaline, and total DH\%) and \% digestibility of the diets using multi-enzymatic extracts of juveniles of Centropomus undecimalis: reference diet (Refd), wheat gluten diet (WGd), chicken meal diet $(C H K M d)$, poultry byproduct diet $(P B P d)$, Pota meal diet $(P M d)$, and Protiblend diet $(P B T d) ., 2$

\begin{tabular}{|c|c|c|c|c|c|}
\hline \multirow[b]{2}{*}{ Diet } & \multicolumn{4}{|c|}{$\mathrm{DH}$} & \multirow[b]{2}{*}{ Digestibility\% } \\
\hline & Stomach & Pyloric caeca & Intestine & Total & \\
\hline Hemoglobin/casein & $0.06 \pm 0.02^{\mathrm{b}}$ & $0.20 \pm 0.06^{\mathrm{a}}$ & $0.26 \pm 0.06^{\mathrm{a}}$ & $0.57 \pm 0.10^{\mathrm{a}}$ & \\
\hline Refd & $0.08 \pm 0.06^{\mathrm{b}}$ & $0.08 \pm 0.06^{\mathrm{ab}}$ & $0.13 \pm 0.04^{\mathrm{a}}$ & $0.34 \pm 0.10^{b}$ & $51 \pm 2.0^{\mathrm{a}}$ \\
\hline WGd & $0.17 \pm 0.06^{\mathrm{a}}$ & $0.04 \pm 0.02^{\mathrm{b}}$ & $0.17 \pm 0.08^{a}$ & $0.34 \pm 0.09^{\mathrm{b}}$ & $51 \pm 1.1^{\mathrm{a}}$ \\
\hline Chkd & $0.2 \pm 0.19^{\mathrm{a}}$ & $0.10 \pm 0.03^{\mathrm{a}}$ & $0.17 \pm 0.08^{\mathrm{a}}$ & $0.5 \pm 0.2^{\mathrm{ab}}$ & $67 \pm 3.5^{\mathrm{a}}$ \\
\hline PBPd & $0.18 \pm 0.13^{\mathrm{a}}$ & $0.08 \pm 0.06^{\mathrm{ab}}$ & $0.17 \pm 0.06^{\mathrm{a}}$ & $0.34 \pm 0.10^{\mathrm{ab}}$ & $61 \pm 5^{\mathrm{a}}$ \\
\hline PMd & $0.23 \pm 0.16^{\mathrm{a}}$ & $0.05 \pm 0.02^{\mathrm{b}}$ & $0.14 \pm 0.07^{\mathrm{a}}$ & $0.42 \pm 0.09^{\mathrm{ab}}$ & $60 \pm 4.2^{\mathrm{a}}$ \\
\hline PBTd & $0.18 \pm 0.06^{\mathrm{a}}$ & $0.10 \pm 0.04^{\mathrm{a}}$ & $0.17 \pm 0.03^{\mathrm{a}}$ & $0.45 \pm 0.07^{\mathrm{ab}}$ & $64 \pm 3.5^{\mathrm{a}}$ \\
\hline
\end{tabular}

${ }^{1}$ The results are presented according to a one-way ANOVA (mean $\left.\pm \mathrm{SE}\right)$.

${ }^{2}$ Different letters in superscript indicate significant differences $(P<0.05)$.

were similar $(P>0.05)$. For the total $\mathrm{DH}$ value of the diets, the lowest values corresponded to the WG diet and reference diet (Ref diet). The digestibility percentages of the diets were not significantly different $(P>0.05$; Table 5$)$.

FAA released in the acidic condition differed in all three time points $(0,6$, and $15 \mathrm{~min})$.
The Ref diet (fishmeal) had the highest values of 1.8 and 1.7 at 6 and $15 \mathrm{~min}$, respectively, followed by PBP (1.1 and 1.2, respectively) and CHKM (1.1 and 1.2, respectively). The diet containing French WG Viten ${ }^{\circledR}$ had the lowest amount of amino acids released $(0.05$ and 0.4 at 6 and $15 \mathrm{~min}$, respectively; Table 2). Under 
TABLE 6. Apparent digestive coefficient (ADC) \% for dry matter $(D M)$, protein, and energy of Centropomus undecimalis (mean $\pm S E){ }^{1}$

\begin{tabular}{lcll}
\hline & $\mathrm{ADC}_{\mathrm{DM}}$ & $\mathrm{ADC}_{\text {protein }}$ & $\mathrm{ADC}_{\text {energy }}$ \\
\hline Reference diet & $67.8 \pm 3.2^{\mathrm{ab}}$ & $91.6 \pm 0.5^{\mathrm{a}}$ & $85.5 \pm 1.8^{\mathrm{b}}$ \\
Wheat gluten diet & $65.8 \pm 3.4^{\mathrm{ab}}$ & $89.9 \pm 1.7^{\mathrm{ab}}$ & $82.2 \pm 3^{\mathrm{b}}$ \\
Chicken meal diet & $74.2 \pm 5.6^{\mathrm{a}}$ & $90.9 \pm 2^{\mathrm{ab}}$ & $90.5 \pm 0.8^{\mathrm{a}}$ \\
Poultry byproduct & $70.9 \pm 6.1^{\mathrm{ab}}$ & $92.9 \pm 1.5^{\mathrm{a}}$ & $82.8 \pm 2^{\mathrm{b}}$ \\
$\quad$ & & & \\
$\quad$ diet & $59 \pm 4.1^{\mathrm{b}}$ & $87.2 \pm 1.1^{\mathrm{b}}$ & $77.3 \pm 2.2^{\mathrm{c}}$ \\
Pota meal diet & $63.9 \pm 5.3^{\mathrm{ab}}$ & $90.5 \pm 1.3^{\mathrm{ab}}$ & $85 \pm 2.5^{\mathrm{b}}$ \\
\hline
\end{tabular}

${ }^{1}$ Different letters in superscript indicate significant differences $(P<0.05)$.

the alkaline conditions, there were no differences at $45 \mathrm{~min}$ for the protein ingredients whether from the caeca $(1.2-2.8)$ or from the intestine (2.4-3.6).

In relation to the in vivo digestibility, significant differences in $\mathrm{ADC}_{\mathrm{DM}}$ were found among the ingredients $(P<0.05)$. The lowest value was obtained in the PM diet (59\%), which was similar to the Ref diet (Table 6). ADC $\mathrm{Arotein}_{\text {dis- }}$ criminated between animal ingredients with the lowest value found in PM $(P<0.05$; Table 6$)$. PBP (93\%) was more digestible than CHKM (91\%). PBP meal and quality WG were similarly ranked (91 and 90\%), which contrasted with the pH-Stat results (Table 6). PM was significantly less digestible than all of the other ingredients based on its ADC. However, no significant differences were observed in relation to the $\mathrm{ADC}_{\text {ingredients }}(P>0.05$; Table 6$)$.

The correlation between the apparent protein digestibility and the degree of hydrolysis of the five ingredients is shown in Figure 1; the regression was not significant $(P>0.05)$.

\section{Discussion}

To the best of our knowledge, this study is the first description of the potential for digestion (in vitro) and absorption (in vivo) of plant and animal ingredients for juvenile $C$. undecimalis. Centropomidae is a family with several species that are good candidates for aquaculture such as snook (Tucker 1987; Zarza-Meza et al. 2006; Tsuzuki et al. 2007) and Asian sea bass (Katersky and Carter 2007). However, the level of knowledge varies from one species to another.

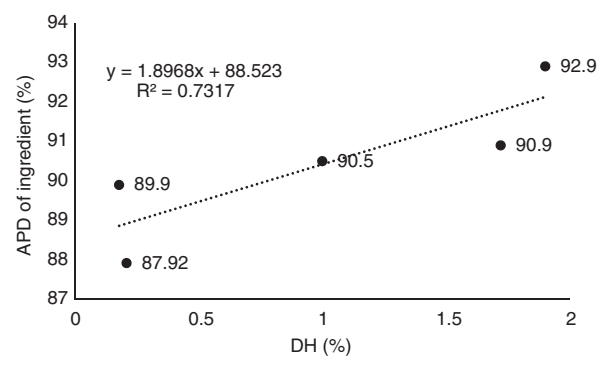

FIGURE 1. The correlation between apparent protein digestibility $(A P D, \%)$ and in vitro degree of protein hydrolysis ( $\mathrm{DH} \%)$ with enzymatic extracts of juveniles of Centropomus undecimalis. Regression not significant $(\mathrm{P}=0.06)$.

Lates calcarifer is known for its capacity to digest SBM as a replacement for fishmeal (Boonyatpalin 1998) and for its digestible protein/digestible energy (DP/DE) requirement. In all three presentations, SBM gave the same DH but the concentrate (soy protein concentrate [SPC]) contained an antinutritional factor (Kunitz 1947; Garcia-Carreno et al. 1997), which could explain an absence of differences between the meal and the concentrate. $C$ undecimalis juveniles were tested at the beginning of their growth potential when their ability to digest dry ingredients was low.

The results of acidic and alkaline protease activities showed high levels in the stomach (acidic) and intestine (alkaline), but the caeca activity remained low, which was similar to previous results reported in snook (Concha 2008). Snook is a colossal carnivorous fish and the main hydrolysis occurs in the stomach while the final hydrolysis is performed in the caeca and intestine, where freed nutrients are available for absorption (mostly in the intestine). The in vitro digestibility in the stomach had a higher DE for various alternative protein sources, such as marine and terrestrial animal flour (PTB), as well as land animal protein (chicken feed grade and chick meal); these results indicate that there are potential alternative protein sources to fishmeal or other marine sources to make feeds (Cho 1992), which meet the nutritional requirements of $C$. undecimalis. However, PM showed a lower value than expected (50\%), which was probably due to processing, a finding that has been previously encountered for shrimp 
(Ezquerra et al. 1997; Córdova-Murueta and García-Carreño 2002).

The plant ingredients produced lower DH values than the control $(\mathrm{Hb})$, which is also indicative of the carnivorous lifestyle of this species. Alkaline digestibility was divided in two parts: the first focused on the pyloric caeca and the second on the intestine. This test showed slight differences when compared to acidic digestibility. Casein in both cases had the highest $\mathrm{DH}$; the only source of marine origin (PTB) had a lower DH compared to plant ingredients (CAN, $\mathrm{CAN}+$ phytase, or CG). The DH from acid and alkali resulted in high \% digestibility for PTB, PBP meal, and CHKM; in the case of animal protein, the digestibility is known to be closest to $100 \%$, but plant-derived ingredients, such as CG and CAN + phytase, also produced values close to $100 \%$. The $\mathrm{DH}$ discriminated between ingredients and for the same ingredients, regardless of whether phytase was added or not (Table 4).

Variations in the DH from different parts of the fish gut were clear when pretreated phytase + CAN and SBM were tested. In the stomach, the extract had no effect on both meals containing phytase. In the caeca and intestine, the phytase used on CAN produced higher $\mathrm{DH}$ values than with SBM (Table 4), which showed that an exogenous enzyme had varying impacts according to the nature of the ingredients fed to the snook.

A comparison of the ADC values (Gomes Da Silva and Oliva-Teles 1998; Lemos et al. 2009) within the Centropomidae family revealed $72 \%$ with Danish fishmeal in snook and 88 and $83 \%$ in Asian seabass for protein and energy, respectively (Williams et al. 2003); $\mathrm{ADC}_{\text {protein }}$ and $\mathrm{ADC}_{\text {energy }}$ for SBM was 86 and $69 \%$, respectively. These data show an optimal $\mathrm{DP} / \mathrm{DE}$ ratio that is fundamentally dependent on digestibility results; with marine fish, only data on Centropomidae were produced by means of the three experiments testing constant DP level, constant energy level, or the constant ratio in $L$. calcarifer. This information permitted creation of a commercial formulation in Singapore to farm seabass (Lee et al. 1995).

In relation to SPC, an antitrypsic factor could concentrate and then alter the protein digestibility results in trout (Escaffre et al. 2007; Sarker et al. 2011) and snook (Grabner and Hofer 1985), which could explain an absence of differences between the meal and the concentrate for soybean.

The ingredients were treated for in vitro or in vivo digestibility while considering primarily the protein content. From all of the potential ingredients, PTB had a high digestibility (DH) because it is a mix of shrimp meal and meat meal. Therefore, the chitin could have been partly digested (amino sugars $\beta 1-4$ bounds). What benefit could Centropomidae retrieve from plant sources? Native WG produced a high DH and $\mathrm{ADC}_{\text {protein }}$. CAN and SBM (meal or concentrate) were equally digested. Therefore, despite a preference for carnivory, Centropomidae maintained a level of digestibility for plant sources in the following order: $\mathrm{WG}>\mathrm{SBM}>\mathrm{CAN}>\mathrm{SPC}$. However, the results did not correlate except for WG and CHKM. The question was also raised for squid (Córdova-Murueta and García-Carreño 2002) that can be ingested by $C$. undecimalis in its environment; its native protein had a high digestibility as well as the native gluten.

The predictive role of $\mathrm{DH}$ of the best ingredients using enzymatic extracts of $C$. undecimalis juveniles was verified through the high positive correlation between the apparent protein digestibility $\left(r^{2}=0.7\right)$; however, the regression was not significant $(P>0.05)$ although all of the values were higher than $80 \%$ as was indicated by Lemos et al. (2009).

Hydrolysis-produced FAAs were released during the in vitro test and did not indicate differences among the parts of the digestive tract $(P>0.05)$. The stomach did not discriminate between WG and other sources after $15 \mathrm{~min}$ and this absence of a difference was maintained in the intestine; all of the other sources released equal amounts of amino acids after $45 \mathrm{~min}$ in the intestine. This indicated a potentially similar efficiency for tissue buildup regardless of the protein sources.

Therefore, the information on digestibility of this fish species can be summarized in a putative formula for a grower feed in the \% fed: PTB, 15; chick meal, 15; chicken feed grade, 10; squid, 5; WG, 5; SBM, 10; SPC, 10; CAN, 
10; and premix, 10 to provide a feed with $42 \%$ crude protein (CP) (34\% DP). From an economics viewpoint, another Centropomidae, L. calcarifer, was studied with two main protein sources (fishmeal and regular SBM) to reach a balanced DP/DE (33 mg protein/kJ), which met the requirement of juveniles with $1.5 \mathrm{~g}$ balanced digestible protein per $64 \mathrm{~kJ}$ for an specific growth rate at $2.4 \%$ (Lee et al. 1995). This preliminary study opens the way for further research with native species to adapt the formulation of feed to their digestive potential and then examine the final cost of feed to produce common snook in floating cages or earthen ponds (Zarza-Meza et al. 2006) along the coast of the Yucatan.

\section{Conclusions}

Generally, juvenile $C$. undecimalis digested and absorbed animal protein sources (marine and/or terrestrial) more effectively. PTB is highlighted, and, aside from PBP and CHKM, only CG was effective among the plant sources. The selection of available plant-based ingredients should be considered not only on the basis of proximate composition but also for soluble fiber and cellulose content. This content is often pooled in NFE to discriminate among CAN, soya, soluble distiller's grain, and millrun and should be considered to formulate on a low-cost basis as well as on the digestive physiology of C. undecimalis.

\section{Acknowledgments}

We thank SAGARPA-CONACYT 164673 for financial support and CONACYT for the scholarship grant to Ms Iratzio Lémus. We thank Jaime Suárez, Claudia Durruty, Gabriela Palomino, Patricia Balan, Korinthya López, and Karla Escalante for the technical assistance.

\section{Literature Cited}

Alarcon, F. J., F. J. Moyano, and M. Diaz. 2002. Evaluation of different protein sources for aquafeeds by an optimised pH-stat system. Journal of the Science of Food and Agriculture 82:697-704.

AOAC. 1980. Associcitonof Oficial Analytical Chemist. POBoax 540, Bejnamin Frianklin Station, Washington DC 20044,
Barroso, M. V., J. C. Castro, P. C. M. Aoki, and J. L. Helmer. 2002. Valor nutritivo de algunas ingredientes para o robalo Centropomus parallelus. Revista Brasiliera Zootecnia. 31:2157-2164.

Boonyatpalin, M. 1998. Replacement of fish meal with various types of soybean products in diets for the Asian sea bass, Lates calcarifer. Aquaculture 161:67-78.

Borquez, A. and V. Cerqueira. 1998. Feeding behavior in juvenile snook, Centropomus undecimalis, individual effect of some chemical substances. Aquaculture 169:25-35.

Bureau, D. and K. Hua. 2006. Letter to editor. Aquaculture 252:103-105.

Cho, C. Y. 1992. Feeding systems for RT and others salmonids with reference to current estimates of energy and protein requirements. Aquaculture 10:1070-1123.

Church, F. C., H. F. Suaisgood, D. H. Porter, and G. L. Calignani. 1983. Spectophotometric assay using phtaladehyde for determination of proteolysis in milk and isolated milk protein. Journal of Dairy Science 66(6): 1219-1227.

Concha, B. 2008. Evaluación de la capacidad digestiva de juveniles del robalo blanco Centropomus undecimalis sobre diferentes ingredientes proteicos. Tesis maestría, Universidad Católica del Norte, Chile.

Córdova-Murueta, J. H. and F. L. García-Carreño. 2002. Nutritive value of squid and hydrolyzed protein supplement in shrimp feed. Aquaculture 210:371-384.

Cuzon, G., J. Guillaume, and C. Cahu. 1998. Composition, preparation and utilization of feeds for crustacean. Aquaculture 124:253-267.

Dimes, L. E. and N. F. Haard. 1994. Estimation of protein digestibility: I. Development of an in vitro method for estimating protein digestibility in salmonids (Salmo gairdneri). Comparative Biochemistry and Physiology 108A:349-362.

Dimes, L. E., F. L. García-Carreño, and N. F. Haard. 1994a. Estimation of protein digestibility. III. Studies on digestive enzyme from the pyloric caeca of rainbow trout and salmon. Comparative Biochemistry and Physiology 109:349-360.

Dimes, L. E., N. F. Haard, F. M. Dong, B. A. Rasco, I. P. Forster, W. T. Fairgrieve, R. Arndt, R. W. Hardy, F. T. Barrows, and D. T. Higgs. 1994b. Estimation of protein digestibility.II. In vitro assay of protein in salmonid feeds. Comparative Biochemistry and Physiology 108A:63-370.

Escaffre, A. M., S. Kaushik, and M. Mambrini. 2007. Morphometric evaluation of changes in the digestive tract of rainbow trout (Oncorhynchus mykiss) due to fish meal replacement with soy protein concentrate. Aquaculture 273:127-138.

Ezquerra, J., F. Garcia-Carreño, and R. Civera. 1997. $\mathrm{pH}$ stat method to predict protein digestibility in white shrimp Penaeus vannamei. Aquaculture 157:251-262.

Garcia-Carreno, FL., Navarrete del Toro, A., and M. Ezquerra. 1997. Destive shrimp proteases for evaluation of protein digestibility in vitro. I: Effect of 
protease inhibitors in protein ingredients. Journal of Marine Biotechnology 5:36-40.

Garcia-Galano, T., J. Pérez, G. Gaxiola, and A. Sánchez. 2003. Effect of feeding frequency of food intake, gastric evacuation and growth in juvenile snook, Centropomus undecimalis (Bloch). Revista de Investigación Marina 24:145-154.

Garcia-Lopez, V. T., G. G.-C. García-Galano, and J. Pacheco-Campos. 2003. Efecto del nivel de proteína en la dieta y alimentos comerciales sobre el crecimiento y la alimentación en juveniles del robalo blanco, Centropomus undecimalis (Bloch, 1792). Ciencias Marinas 29:585-594.

Gomes Da Silva, J. and A. Oliva-Teles. 1998. Apparent digestibility coefficients of feedstuffs in seabass (Dicentrarchus labrax) juveniles. Aquatic Living Resources 11:187-191.

Grabner, M. and R. Hofer. 1985. The digestibility of the proteins of broad bean (Vicia faba) and soya bean (Glycine max) under in vitro conditions simulating the alimentary tract of rainbow trout (Salmo gairdneri) and carp (Cyprinus carpio). Aquaculture 48:111.

Ibarra-Castro, L., L. Alvarez-Lajonchere, C. Rosas, I. Palomino-Albarran, J. G. Holt, and A. Sanchez. 2011. GnRH induced spawning with natural fertilization and pilot scale juvenile mass production of common snook Centropomus undecimalis (Bloch, 1792). Aquaculture 319:479-483.

Izquierdo, P., G. Torres, M. Allara, T. Marques, Y. Barboza, and E. Sanchez. 2001. Análisis proximal, contenido de aminoácidos esenciales y relación calcio/fosforo, en algunas especies de pescado. Revista Científica 11:95-100.

Katersky, R. and C. Carter. 2007. High growth efficiency occurs over a wide temperature range for juvenile barramundi Lates calcarifer fed a balanced diet. Aquaculture 272:444-450.

Kunitz, M. 1947. Crystalline soybean trypsin inhibitor II. General properties. Journal of General Physiology 30:291-310.

Lee, P. G. and A. L. Lawrence. 1986. Effects of diet and size on growth, feed digestibility and digestive enzyme activities of the marine shrimp, Penaeus setiferus Linnaeus. Journal of the World Aquaculture Society 16:275-287.

Lee, H. B., J. Guillaume, R. Chou, G. Cuzon, H. H. Heng, J. Fuchs. 1995. Methodology in the study of seabass (Lates calcarifer Bloch): nutritional requirements in Singapore. Journal of Applied Ichthyology 11:3-4.

Lemos, D., A. L. Lawrence, and A. J. Siccardi III. 2009. Prediction of apparent protein digestibility of ingredients and diets by in vitro $\mathrm{pH}$-stat degree of protein hydrolysis with species-specific enzymes for juvenile Pacific white shrimp Litopenaeus vannamei. Aquaculture 295:89-98.

Moyano, F. and L. Savoie. 2001. Comparison of in vitro systems of protein digestion using either mammal or fish proteolytic enzymes. Comparative Biochemistry and Physiology 128:359-368.
Pedersen, B. Y. and B. O. Eggum. 1983. Prediction of protein digestibility by an in vitro enzymatic ph-stat procedure. Journal of Animal Physiology and Animal Nutrition 49:265-277.

Sarker, P. K., J. Fournier, E. Boucher, E. Proulx, J. de la Nouee, G. W. Vandenberg. 2011. Effects of low phosphorus ingredient combinations on weight gain, apparent digestibility coefficients, non-fecal phosphorus excretion, phosphorus retention and loading of large rainbow trout (Oncorhynchus mykiss). Animal Feed Science and Technology 168:241-249.

Saunders, R. M., M. A. Conner, A. N. Booth, E. M. Bickoff, and G. O. Kohler. 1972. Measurement of digestibility of alfalfa concentrates by in vivo and in vitro methods. Journal of Nutrition 103:530-535.

Shimada, J., L. Nogueira, V. Gomes, and J. Machado. 2010. Lipidic and proteic absorption in digestive tract of tropical fat snook (Centropomus parallelus, Poey 1860). Journal of Experimental Marine Biology and Ecology 386:39-44.

Silva, A., K. Escalante, A. Alvarez-González, M. Guerrero-Olanzaran, G. Cuzon, and G. Gaxiola. 2014. Protein sources evaluation for juvenile red grouper Epinephelus morio by $\mathrm{pH}$-stat with species-specific enzymes. The Israeli Journal of Aquaculture-Bamidgeh 64:1069.

Smith, D. M. and S. J. Tabrett. 2008. Método desarrollado por el CSIRO para medir digestibilidad in vivo en camarón. in L. E. Cruz Suarez, H. V. Colmenares, M. T. Salazar, M. G. Nieto Lopez, D. A. Villarreal Cavazos, and D. Ricque, editors. Manual de metodologías de digestibilidad in vitro e in vivo para ingredientes y dietas para camarón. UANL, Nuevo León, Mexico.

Soria-Cuenca, A. C., C. A. Alvarez-Gonzalez, J. L. Ortiz-Galindo, R. Guerrero-Zarate, and M. A. Perera-Garcia. 2013. In vitro $\mathrm{pH}-\mathrm{Stat}$ digestibility of protein ingredients in the Mayan Cichlid Cichlasoma urophthalmus. Universidad y Ciencia 29(3):263.

Tibbetts, S. M., J. E. Milley, N. W. Ross, J. A. J. Verreth, and S. P. Lall. 2011. In vitro $\mathrm{pH}$-stat protein hydrolysis of feed ingredients for Atlantic cod (Gadus morhua), development of the method. Aquaculture 319:398-406.

Tsuzuki, M., J. Sugai, C. Maciel, C. Francisco, and V. Cerqueira. 2007. Survival, growth and digestive enzyme activity of juveniles of the fat snook (Centropomus parallelus) reared at different salinities. Aquaculture 271:319-325.

Tucker, J. 1987. Snook and tarpon culture: preliminary evaluating for commercial farming. Progressive Fish Culturist 49:49-57.

Viader-Salvadó, J. M., J. A. Gallegos-López, J. G. Carreón-Treviño, M. Castillo-Galvan, A. RojoDominguez, M. Guerrero-Olanzarán. 2010. Dseign of thermostable beta propeller phytases with activity over a broad range of $\mathrm{pHs}$ and their overproduction by Pichya pastoris. Applied Environemental Microbiology 76(16):6423-6430. 
Wainwright, P., S. Huskey, R. Turingan, and A. Carrol. 2006. Ontogeny of suction feeding capacity in snook, Centropomus undecimalis. Aquaculture 305:246-252.

Walter, H. E. 1984. Proteinases: methods with hemoglobin. casein and azocoll as substrates. In: Bergmeyer. H.U. (Ed). Methods of enzimatic analysis. Vol. V. Verlag Chemie. Weinheim. p. 270-277.

Williams, K. C., C. G. Barlow, L. J. Rodgers, and I. Ruscoe. 2003. Potential of meat meal to replace fish meal in extruded dry diets for barramundi, Lates calcarifer (Bloch). I. Growth performance. Aquaculture Research 34:23-32.

Zarza-Meza, E., J. Berruecos-Villalobos, C. Vásquez-Pelaez, and P. Alvarez-Torres. 2006. Cultivo experimental de robalo Centropomus undecimalis y chucumite Centropomus parallelus (Perciforme:Centropomidae) en estanques rústicos de tierra. Ciencias Marinas 32. 